\title{
"NEW" COSSACK TROOPS IN GOVERNMENT PROJECTS AND OFFICIAL NOTES OF THE 1860s
}

\author{
Alexey A. Volvenko \\ Taganrog Institute named after A.P. Chekhov (branch) RSUE (RINH), Taganrog, Russian Federation
}

\begin{abstract}
Introduction. The article considers the government policy for the Cossacks in the 1860s. During this period, the processes of organization/reorganization of the Cossack troops were most brightly shown. These processes were developed against the background of discussions between imperial officials about the roles and values of the Cossacks from the point of view of his military and colonization potential. Only the Semirechensky (Almaty) army created in 1867 was a "new" Cossack army for the empire. Methods and materials. As the main material for writing the article the contemporary records found in the $330^{\text {th }}$ fund of the Russian state military and historical archive (Moscow) and the Historical archive of Omsk region (Omsk) served. The note of the chief of Tersky region in 1863-1875 M.T. Loris-Melikov "About education of the Transcaucasian Cossack army", prepared in December, 1868, is of particular importance. The specifics of the sources attracted required the use of methods of source studies in accordance with the type of documents under consideration, followed by the structural analysis of the identified data based on the systematic approach. Discussion. The announced subject is poorly developed in historical literature, and only the studying of Semirechensky Cossack army history has a long tradition. Separately, the question of the place of the Cossacks in the projects for the administrative structure of the Central Asian possessions of the empire and plans for the training of new troops, except for Semirechensk, has not yet been considered in historiography. Analysis. At the initiative of the governor general of Western Siberia A.P. Khrushchov in 1867-1868, projects on the organizations of the Irtysh, Akmola, Semipalatinsk Cossack troops, as well as plans for the resettlement of the Cossacks to the lands bordering Western China, were prepared. Despite the support of the initiatives of A.P. Khrushchov from the Minister of War D.A. Milyutin and the Steppe commission, the projected Cossack troops nevertheless were not created, and the Cossack colonization of border territories did not take place. The negative decision of the authorities was also made on the note of the chief of Tersky region M.T. Loris-Melikov "About education of the Transcaucasian Cossack army" (1868). Conclusions. The article examines the reasons why colonization plans and projects for the creation of new Cossack troops were unclaimed in the 1860s.
\end{abstract}

Key words: Empire, government policy, colonization, Cossacks, projects, Irtysh, Akmola, Semipalatinsk, Transcaucasian and Semirechensky (Almaty) Cossack troops, A.P. Khrushchov, Steppe commission, M.T. Loris-Melikov.

Citation. Volvenko A.A. "New" Cossack Troops in Government Projects and Official Notes of the 1860s. Vestnik Volgogradskogo gosudarstvennogo universiteta. Seriya 4. Istoriya. Regionovedenie. Mezhdunarodnye otnosheniya [Science Journal of Volgograd State University. History. Area Studies. International Relations], 2021, vol. 26, no. 2, pp. 68-79. (in Russian). DOI: https://doi.org/10.15688/jvolsu4.2021.2.5

\section{«НОВЫЕ» КАЗАЧЬИ ВОЙСКА В ПРАВИТЕЛЬСТВЕННЫХ ПРОЕКТАХ} И ЧИНОВНИЧЬИХ ЗАПИСКАХ 1860-х ГОДОВ

\author{
Алексей Александрович Волвенко \\ Таганрогский институт им. А.П. Чехова (филиал) \\ Ростовского государственного экономического университета (РИНХ), \\ г. Таганрог, Российская Федерация
}


Аннотация. В статье рассматривается правительственная политика в отношении казачества в 1860-х годах. В эти годы наиболее ярко проявились процессы организации/реорганизации казачьих войск. Данные процессы развертывались на фоне дискуссий между имперскими чиновниками о роли и значении казачества с точки зрения его военного и колонизационного потенциала. «Новым» казачьим войском для империи оказалось лишь Семиреченское (Алматинское) войско, созданное в 1867 году. По инициативе генерал-губернатора Западной Сибири А.П. Хрущова в 1867-1868 гг. были подготовлены проекты по организации Иртышского, Акмолинского, Семипалатинского казачьих войск, а также планы по переселению казаков на приграничные с Западным Китаем земли. Несмотря на поддержку инициатив А.П. Хрущова со стороны военного министра Д.А. Милютина и Степной комиссии, проектируемые казачьи войска все же созданы не были, также не состоялась и казачья колонизация приграничных территорий. Отрицательное решение властей последовало и по записке начальника Терской области М.Т. Лорис-Меликова «Об образовании Закавказского казачьего войска» (1868). В статье разбираются причины, по которым колонизационные планы и проекты по созданию новых казачьих войск оказались невостребованными в 1860-х годах.

Ключевые слова: Империя, правительственная политика, колонизация, казачество, проекты, Иртышское, Акмолинское, Семипалатинское, Закавказское и Семиреченское (Алматинское) казачьи войска, А.П. Хрущов, Степная комиссия, М.Т. Лорис-Меликов.

Цитирование. Волвенко А. А. «Новые» казачьи войска в правительственных проектах и чиновничьих записках 1860-х годов // Вестник Волгоградского государственного университета. Серия 4, История. Регионоведение. Международные отношения. - 2021. - Т. 26, № 2. - С. 68-79. - DOI: https://doi.org/10.15688/ jvolsu4.2021.2.5

Введение. История казачества, отдельных казачьих войск является неотъемлемой частью имперского нарратива. Кавказская война вряд ли может быть рассмотрена без участия в ней полков Кубанского (Черноморского), Терского (Кавказского линейного), Донского войск, освоение Сибири и присоединение Средней Азии в основном легло на плечи казачества Азиатской части России, наконец, практически ни одна из войн XVIII - начала $\mathrm{XX}$ в. не обошлась без наличия казаков в составе действующей русской армии. Наряду с так называемыми «природными» казачьими войсками, созданными с минимальной поддержкой со стороны государства, существовали и такие казачьи сообщества, которые своим рождением были полностью обязаны имперскому центру. Условная номенклатура войск и частей не являлась постоянной, она могла как пополняться новыми участниками, так и сокращаться за счет реорганизованных ее членов. В данной статье мы акцентируем внимание на 1860-х гг, отличающихся активной правительственной политикой в отношении казачества. Именно в эти годы, на наш взгляд, процессы организации/реорганизации казачьих войск проявились наиболее ярко. Ведущиеся в 1860-х гг. дебаты о функциональных качествах казаков косвенно способствовали появлению радикальных планов по организации новых войск, переселению казаков, переброске их ближе к границам других государств и пр. Основное внимание будет уделено образованию Семиреченского (Алматинского) казачьего войска, свидетельствующее о сохранении актуальности для имперских властей опыта по использованию пограничных и колонизационных функций казачества. Кроме того, анализ содержания планов по устройству Иртышского, Акмолинского, Семипалатинского и Закавказского казачьих войск, в итоге так и нереализовавшихся на практике, покажет неоднозначное отношение к казачеству со стороны различных высших чиновников и ведомств, включая «профильное» для казаков Главное управление иррегулярных войск (далее - ГУИВ).

Методы и материалы. Основным материалом для написания статьи послужили архивные данные, обнаруженные в 330-м фонде Российского государственного военно-исторического архива (г. Москва) и Историческом архиве Омской области (г. Омск). В их число входит переписка чиновников Главного управления иррегулярных войск (далее ГУИВ) с генерал-губернатором Западной Сибири А.П. Хрущовым по его предложениям по организации Иртышского, Акмолинского и Семипалатинского казачьих войск, письма военного министра Д.А. Милютина к различным должностным лицам по казачьим вопросам, проекты положений о хозяй- 


\section{ВЛАСТЬ И ОБЩЕСТВО}

ственном правлении и военных округах Акмолинского и Семипалатинского войск и пр. $[17 ; 18 ; 20]$. Отдельную ценность представляет собой записка начальника Терской области в 1863-1875 гг. М.Т. Лорис-Меликова «Об образовании Закавказского казачьего войска», подготовленная в декабре 1868 г. и прочитанная лично Александром II [19]. Она была опубликована нами в 2009 г., с небольшим разъясняющим введением, но без подробных комментариев и критики ее содержания [7]. Привлекаемые архивные источники рассматриваются с учетом их видовых особенностей, с последующим структурным анализом выявленных сведений на основе системного подхода. Такой подход позволил раскрыть взаимосвязь между полемикой представителей имперского центра и генерал-губернаторами окраинных земель о способах освоения завоеванных пространств и содержанием проектов по использованию казачества и его войсковых структур в качестве важного колонизационного ресурса, а также ответить на вопрос - почему организация новых казачьих войск в 1860-1870-х гг. так и осталась в планах высшей власти.

Обсуждение. Заявленная нами тема в исторической литературе разработана слабо. Пожалуй, только изучение истории Семиреченского казачьего войска имеет свою давнюю традицию. Благодаря трудам М.П. Хорошхина, коллектива авторов 11 тома «Столетия Военного министерства», посвященного казачьим войскам России [25], и особенно книги Н.В. Леденева «История Семиреченского казачьего войска» [13], была зафиксирована основная событийная канва исторического пути, пройденного войском до 1917 года. В советское время упоминание о семиреченских казаках делалось эпизодически и, как правило, в контексте завоевания Средней Азии, колониальной политики самодержавия и охраны государственной границы. Редкие издания казаков-эмигрантов не внесли ничего принципиально нового в картину жизни Семиреченского войска, созданную еще в дореволюционный период. Известные события 1990-х гг. актуализировали интерес к истории казачества, в том числе семиреченского, причем не только в России, но и Казахстане, Кыргызстане, на территории которых оказались бывшие земли Се- миреченского войска. В публикациях и диссертационных исследованиях М.Ж. Абдирова [1;2], 3.С. Актамбердиевой [3], И.В. Анисимовой [4], Е.Н. Лещева [14], Т.Б. Митропольской [16], Д.А. Сапунова [23], Л.М. Сатановой [24], А.П. Яркова [26] и других отражены различные аспекты жизнедеятельности семиреченского казачества как организованного войскового сообщества. Однако в осмыслении вопроса - каков был механизм непосредственного образования Семиреченского войска в 1867 г., кто его запустил и какие дискуссии этому сопутствовали упомянутые авторы в основном опирались на достижения дореволюционной историографии. Отдельно следует отметить публикации современных исследователей, которые занимаются изучением административной политики самодержавия в Степном крае в XIX в., деятельности Степной комиссии, образования Туркестанского генерал-губернаторства и пр. В работах представителей данного направления (Е.В. Безвиконной [5], Д.В. Васильева [6], А.В. Ремнева и Н.Г. Суворовой [21] и др.) тема казачества занимает далеко не первое место, однако казаки, так или иначе, фигурируют в привлекаемых для исследования документах, в которых им отводятся различные роли в покорении, заселении и колонизации Степного края. Таким образом, отдельно вопрос о месте казачества в проектах по административному устройству среднеазиатских владений империи и планах по образованию новых войск, за исключением Семиреченского, в историографии еще не рассматривался. Что касается планов по созданию Закавказского казачьего войска, то, как уже было отмечено выше, в 2009 г. мы опубликовали соответствующую записку М.Т. Лорис-Меликова по этому поводу. Ее использовал О. Кузнецов в статье «Закавказское казачье войско: три несостоявшихся проекта» [12]. Основной упор он сделал на анализе инициатив властей по организации казачьих войсковых структур в Закавказье I половины XIX века. Разбирая же предложение Лорис-Меликова, Кузнецов ограничился замечанием об этно-конфессиональной подоплеке планируемого переселения казаков на приграничные с Османской империей земли. По его мнению, неудача проектов по образованию Закавказского казачьего войска свя- 
зана с тем, что «все они были продиктованы выгодами и интересами отдельных высокопоставленных государственных чиновников и стоявших за ними региональных элит. Ни один из этих проектов не учитывал интересов всех сил, представляющих власть и общество в Закавказье» [12, с. 27]. Как нам представляется, данное объяснение вряд ли можно признать исчерпывающим.

Анализ. В 1860-е гг. дискуссии о роли и значении казачества, ведущиеся в периодической печати, на заседаниях различных комиссий и комитетов центральных и местных органов власти, становятся более активными и насыщенными. В это время встречаются разные оценки казачества, но все же доминирующим оставалось мнение, зафиксированное во Всеподданнейшем отчете Управления иррегулярных войск за 1859 год. В отчете утверждалось, что назначение казачества «состоит, с одной стороны, в непосредственном охранении границ империи от враждебных племен и сохранении порядка и спокойствия между кочующими на юго-восточных пределах оной инородцами, не вполне еще усвоивших себе условия гражданского быта, с другой же - в содействии военному и гражданскому ведомствам в содержании таможенной и полицейской стражи на других пунктах государства и для усиления, на случай войны, регулярных войск легкою конницею и конною артиллерию» [9, с. 239]. Позднее эта мысль была более конкретизирована в сторону раскрытия именно пограничных и колонизационных функций казачьих войск. Так, в Высочайшем рескрипте Александра II от 24 июня 1862 г. казакам отводилась следующая роль - «казачье сословие предназначено в государственном быту для того, чтобы оберегать границы Империи, прилегающие к враждебным и неблагоустроенным племенам и заселять отнимаемые у них земли» [25, с. 372]. Такой акцент, впрочем, объясняется содержанием рескрипта, который за счет предоставляемых льгот был призван успокоить кубанских казаков, выступивших против правительственных планов по их переселению в предгорные районы Западной части Кавказского хребта. Одновременно он напоминал казакам об их предназначении в интерпретации самого монарха. Нельзя сказать, что вышеприведенные слова рескрипта звучали как-то принципиально поновому. Однако способ использования казачества, изложенный в упомянутых двух документах, актуализировался с окончанием Кавказской войны и «замирением» степи. Такой подход приносил соответствующие плоды, в том числе и негативного для казачества характера. В начале 1860-х гг. под реорганизацию попали Черноморское и Кавказское линейное казачьи войска (на их основе появились Кубанское и Терское войска), были ликвидированы Азовское (1865) и Новороссийское (1868) войска как лишившиеся пограничного статуса (местные казаки переводились в податное сословие или переселялись на Кавказ для усиления «русского» элемента), перестало существовать иррегулярное Башкирское войско (1865), о необходимости упразднить Оренбургское войско, оказавшееся уже не на передних рубежах обороны от кочевников и «утратившее воинственность», открыто говорил Оренбургский и Самарский генерал-губернатор А.П. Безак [8, с. 38] и пр. Создание же Семиреченского войска в июле 1867 г. является примером правительственной политики в отношении казачества, подчеркивающим важность пограничных и колонизационных функций казачества. И в этом случае вряд ли был точен Н.В. Леденев, который в возникновении Семиреченского войска увидел «стечение чисто случайных обстоятельств» [13, с. 199]. Под ними он понимал последствия от образования в 1867 г. Туркестанского генерал-губернаторства из Сыр-Дарьинской и части Семипалатинской областей. Сибирское казачье войско, станицы которого располагались в Семипалатинской области, оказывалось бы разделенным на две части с подчинением разным властям - новым Туркестанским и прежнему - Западно-Сибирскому генерал-губернатору. По мнению Н.В. Леденева: «Для устранения такого затруднения... оставалось одно средство - выделить сибирские поселения, отходящей к Туркестанской части Семипалатинской области, в особое от Сибирского самостоятельное казачье войско» [13, с. 199]. Это верное в целом наблюдение Н.В. Леденева выглядит все же явным упрощением. Безусловно, образование Семиреченского войска следует отнести к косвенным результатам процесса административного переустройства 
Степного края. Как известно, этот процесс был инициирован совместным заявлением МИД, МВД и Военного министерства в виде записки «О преобразовании Азиатской России» от 19 февраля 1863 г., а также замечанием Александра II о том, что «разделение степи между Оренбургом и Омском не соответствует нынешним видам правительства» [17, л. 1]. Причем первоначальная административная конфигурация среднеазиатских владений виделась императору следующим образом: «соединить и подчинить одному начальнику области Оренбургских и Сибирских киргизов, Семипалатинскую, Сыр-Дарьинскую линии, Туркестан и прочие вновь покоренные части, казачьи войска Уральское, Оренбургское и Сибирское, Оренбургскую губернию, все войска в этой местности» $[17$, л. 2]. Реализовать императорскую инициативу планировалось к лету 1865 года. Однако она потребовала более глубокой проработки. В связи с этим были начаты дискуссии среди представителей высшего чиновничества как в имперском центре, так и на местах, в том числе и по таким проблемам, которые имели секретный характер даже для некоторых генерал-губернаторов. Идущие дискуссии подкреплялись результатами проектной деятельности местных администраций. Поступающие предложения рассматривались на заседаниях работавшей с июля 1865 г. «Степной комиссии», которая должна была выработать оптимальный вариант будущего административного и судебного переустройства степных территорий. Именно в рамках этой деятельности тема казачества неоднократно поднималась в различных проектах, авторы которых с легкостью создавали на бумаге новые казачьи войска, меняли прежние их названия, места дислокации, переводили казаков в разряд гражданского (податного) населения и пр. Такое «легкое» отношение к переустройству казачества Азиатской части империи К. Мацузато объяснял тем, что «исторически сложившееся казачество - донское и уральское - пользовалось определенным уважением государственной администрации, а казачьи войска, созданные правительством, вызывали крайнее пренебрежение у чиновников» $[15$, с. 96$]$. О подобной тенденции, только с упором на анализе критических замечаний современников по поводу низкой эффективности колонизаторского потенциала казачества, писали в 2011 г. А.В. Ремнев и Н.Г. Суворова [22]. Конечно, можно задаться вопросом - а насколько упомянутые современными историками мнения о казачестве были доминирующими и влиятельными в казачьем дискурсе 1860-х гг., насколько они учитывались при формировании казачьей правительственной политики? Как нам представляется, данный вопрос остается открытым. Тем не менее все же следует признать, что в 1860-х гг., в том числе с подачи военного министра Д.А. Милютина, имперский центр исповедовал инструменталистский подход к оценке и использованию казачества. Этот подход подразумевал игнорирование истории, традиций, былых заслуг казачества, если необходимо было результативно, с точки зрения властей, решить актуальные государственные задачи во внешней и внутренней политике империи. Таким образом, образование Семиреченского войска необходимо рассматривать с учетом проводимого курса в отношении казачьих войск в 1860-х годах.

Официальная история Семиреченского войска ведется с июля 1867 года. Но старшинство семиреченские казаки сохранили с 1582 года. Таким образом, подчеркивалась их «родовая» связь с Сибирским казачьим войском. Напомним, что Семиреченское войско образовалось из бывших 9-го и 10-го полковых округов Сибирского войска, соответствовавших Алатавскому и Сергиопольскому округам Семипалатинской области, которые летом 1867 г. вошли в состав нового Туркестанского военного округа (генерал-губернаторства). До апреля 1867 г. в документах Военного министерства фигурировало название «Алматинское» для нового казачьего войска, но уже с мая в проектах и переписке чиновников утверждается привычное наименование «Семиреченское» $[18$, л. 132]. Войско, в начале своего пути насчитывавшее 7484 души мужского пола для комплектования 2 конных полков, управлялось на основе «временных начал», взятых из положения о Сибирском казачьем войске. Однако на перспективу Военный Совет «признал возможным военно-административную и хозяйственную части войска, а также станичный суд устроить на основаниях, действующих в Оренбургском казачьем 
войске, и, кроме того, подчинить это войско, по примеру Оренбургского же, в административном, полицейском и судебном отношениях общим в области административным, полицейским и судебным властям» [25, с. 383]. Туркестанский генерал-губернатор как командующий войсками всего военного округа осуществлял свои властные функции по отношению к семиреченским казакам через наказного атамана, который, в свою очередь, являлся военным губернатором и командующим войсками Семиреченской области [25, с. 384].

Разделение Сибирского казачьего войска и планы по административно-территориальной перекройке степных областей способствовали появлению новых инициативных проектов со стороны местных администраций с их видением будущей конфигурации подвластных земель. Один из таких проектов связан с именем генерал-губернатора Западной Сибири А.П. Хрущова (1866-1874). Летом 1867 г. он предложил из оставшейся части Семипалатинской области и Области Сибирских киргизов образовать отдельную Иртышскую область с центром в г. Омске. Ее военный губернатор должен был взять на себя управление Сибирским казачьим войском в качестве наказного атамана, а само войско, в свою очередь, должно было переименоваться в «Иртышское» [20, л. 9-10]. План Хрущова обсуждался в различных высших инстанциях, но реализован все же не был. Дело в том, что Степная комиссия признала необходимость сохранения Семипалатинской области даже в «урезанном» виде с прежним ее подчинением Западно-Сибирскому генерал-губернатору [20, л. 140-167]. Данное решение, поддержанное императором, не остановило желание Хрущова реорганизовать Сибирское казачье войско. В связи с образованием новой Акмолинской области Хрущов предложил сибирских казаков разделить на две части или на два войска. Причем это была не просто брошенная фраза в очередном генерал-губернаторском отчете, а подкрепленный соответствующими документами проект о создании Акмолинского и Семипалатинского казачьих войск (первоначально в названии каждого войска присутствовало слово «Сибирско-»)). О серьезности намерений Хрущова свидетельствуют составленная ведомость «упраздняемым местам и лицам в Сибирском казачьем войске», подготовленные штаты хозяйственных правлений и положения о военных округах новых казачьих войск, а также «расписание станиц и выселков Сибирского войска», которые должны были поступить в Акмолинское и Семипалатинское казачьи войска [20, л. 217-222]. Члены Степной комиссии также высказались в пользу фактической ликвидации Сибирского войска [20, л. 267 об.]. В марте 1868 г. по этому вопросу выразил свою точку зрения и военный министр Д.А. Милютин. По его мнению, предложение Хрущова вполне могло быть воплощено в жизнь, но «на началах, принятых для Оренбургского войска, а устройство штабов в Области Семипалатинской и Акмолинской необходимо всего ближе согласовать с устройством военных управлений в Областях Кубанской и Терской, а также в Семиреченской и Сыр-Дарьинской» [20, л. 246]. Результаты работы Степной комиссии, а также различные проекты, так или иначе связанные с ее деятельностью, но подготовленные местными властями, в том числе и желание Хрущова разделить Сибирское войско, обсуждались на заседаниях особого комитета при Военном министерстве весной - летом 1868 года. Однако и в этот раз инициатива Хрущова не была поддержана. Комитет признал необходимым Сибирское казачье войско «включить в состав Семипалатинской и Акмолинской областей, не образовывая из этих частей особых казачьих войск с новыми названиями, причем генералгубернатору Западной Сибири присвоить звание войскового атамана Сибирского войска, а военным губернаторам Семипалатинской и Акмолинской областей права и обязанности наказных атаманов» [20, л. 271-271 об.]. Как нам представляется, очередная неудача Хрущова была обусловлена позицией ГУИВ по отношению к вопросу о разделении Сибирского войска. Выделим наиболее существенные замечания ГУИВ по Хрущовскому проекту. Так, например, для новых казачьих войск Хрущов планировал создать «только одни военно-окружные управления, не учреждая никакого центрального или войскового органа управления». По мнению же чиновников ГУИВ, «при таком порядке едва ли можно ожидать какого-либо единства в действиях военной администрации новых казачьих 


\section{ВЛАСТЬ И ОБЩЕСТВО}

войск» [20, л. 261 об.]. В связи с этим ГУИВ признало необходимым учредить «если не постоянные центральные военно-административные учреждения, то, по крайней мере, по одному военно-административному отделению при войсковых хозяйственных управлениях» [20, л. 261 об.]. Несмотря на то что обнаружить полностью отрицательного заключения на предложение Хрущова нам не удалось, тем не менее, у нас сложилось твердое убеждение, что именно чиновники ГУИВ, имея уже представление об объеме работ по организации Семиреченского войска, сделали все возможное для предотвращения появления еще двух новых казачьих войск. Очевидно, что данный процесс вел к неминуемой интенсификации деятельности ГУИВ и тем самым мог не соответствовать чиновничьим интересам. Иначе говоря, Сибирское казачье войско осталось существовать по причинам бюрократического характера, а не эмоционально-символическим, связанным, например, с сохранением исторического наследия эпохи покорения Сибири или уважением к казачьим традициям.

Об истинных мотивах проектной деятельности Хрущова по отношению к Сибирскому казачеству можно только догадываться, но то, что он мыслил в духе основных предложений Степной комиссии, - это несомненно. На наш взгляд, именно Степная комиссия в середине 1860-х гг. наиболее критично подошла к оценке роли и значения казачьих войск, по крайней мере, в колонизации среднеазиатских владений. По мнению комиссии, казачьи поселения в степи первоначально устраивались «для установления тишины и порядка в крае», а не для его экономического освоения. И в этом смысле казаки свою роль уже исполнили. Замкнутость казачьего сословия, предоставленные казакам привилегии и обязательная военная служба, отрывающая их от домашних занятий, «не могут не вредить правильному развитию хозяйства и земледелия, и оказывают неблагоприятное влияние на экономическое развитие страны». Таким образом, «продолжение колонизации этим (казачьим. $-A$. $B$.) способом не принесет ожидаемой пользы», но и отказываться от нее нельзя. Комиссия пришла к убеждению, что «для водворения русского населения в крае остается только свободная колонизация, которая может быть земледельческая или промышленная» $[20$, л. 162.]. Тем не менее комиссия все же не списала казачество окончательно со счетов. В одном из ее заключений утверждалось следующее: «Если колонизация казачьим сословием внутри степи отжила свой век, то нельзя не признать ее не только полезною, но даже необходимою на окраинах государства, здесь казаки, исполняя свое историческое призвание - охранять границы Империи, будут полезны и в киргизских степях» [20, л. 162]. Такой взгляд на предполагаемую «новую» роль казачества разделял и А.П. Хрущов. Он был одним из инициаторов предложения заселить казаками территории, непосредственно граничащие с Западным Китаем. К рассмотрению этого вопроса весной 1868 г. ГУИВ подошел отдельно. Согласно его экспертному мнению возможное переселение казаков на китайскую границу должно «исходить из порядка, примененного к азовским казакам при заселении предгорий Западного Кавказа, то есть переселение не должно быть обязательным: тот, кто желает оставаться в казачьем сословии, обязан переселиться, не желающий... должен подлежать обращению в гражданское состояние» [20, л. 262-262 об.]. Надо сказать, что и эта идея Хрущова / Степной комиссии в конце 1860 -х гг. поддержана не была. К ней вернулись, но уже в несколько ином виде, на закате XIX века. На наш взгляд, главную роль в отсрочке решения казачьего переселенческого вопроса вновь сыграло ГУИВ. Точнее, полученный им негативный опыт при организации без должной подготовки переселения части казаков Кубанского войска на предгорные и горные пространства Западного Кавказа в начале 1861 года. Тогда казаки Хоперского полка и Ейского округа отказались участвовать в колонизации закубанских земель, сославшись на «разорительные» условия переселения [11]. Почти такие же обстоятельства с проявлением открытого недовольства сложились и с казачьими переселенцами из упраздняемого Азовского войска [10, c. 29-32]. Для усмирения казаков были направлены регулярные войска, произведены аресты зачинщиков протестных акций, но и властям пришлось пойти на определенные уступки. Одной из целей поездки Александра II в 1861 г. на Кавказ являлась демонстрация 
личного участия императора в деле колонизации завоеванных территорий. Последующая серия мероприятий, закрепляющая вольный характер переселения (и не только казаков) с предоставлением ряда льгот, заложила основы прочной колонизации Кавказа. Мы уверены в том, что в случае с заселением приграничных территорий с Западным Китаем ГУИВ не хотело повторения ситуации с возникновением массового казачьего недовольства, только недавно купированного с помощью авторитета монарха. Более того, ссылку в заключении ГУИВ на принцип добровольности участия азовских казаков (с сохранением своего статуса) в переселении мы интерпретируем как сознательный чиновничий ход. Он подводил возможную реализацию инициативы Хрущова / Степной комиссии под заранее неопределенный результат, так как нужного количества казаков, согласившихся остаться таковыми и быть переселенными на необжитые, приграничные земли, вряд ли бы набралось, по крайней мере в конце 1860-х годов.

Как нам представляется, причины подобного характера повлияли на то, что в целом одобренная Александром II записка начальника Терской области М.Т. Лорис-Меликова «Об образовании Закавказского казачьего войска» все же не была реализована на практике.

Подготовленная М.Т. Лорис-Меликовым в декабре 1868 г. записка была прочитана императором только в январе 1870 года. Коротко напомним ее содержание. Лорис-Меликов начинает свою записку с констатации очевидного для него факта - «изменения значения Кубанского и Терского казачьих войск как элемента колонизации и местной военной силы». И хотя он признает, что казаки являются «лучшим залогом сохранения спокойствия на Северном Кавказе», тем не менее, в записке говорится о том, что «активная роль казачества уже едва ли окажется здесь необходимою». По мнению Лорис-Меликова, казаки стали нести «скорее полицейскую, чем военную службу; прежняя же внешняя служба в составе действовавших против горцев отрядов заменилась кордонными обязанностями на Персидско-Турецкой границе». То есть Кубанское и Терское войска становятся похожими на Донское войско, «приобретая... значение войск внутренних». Лорис-Меликов упоминает о правитель- ственном курсе по отношению к казачеству, проводимом с упором на развитие, прежде всего, его гражданской сферы. Мероприятия, реализуемые в рамках данного курса, как считает начальник Терской области, «вызовут в некоторой части казачьего населения скорее противодействие, нежели поддержку». ЛорисМеликов неоднократно возвращается к мысли о том, что если такому «противодействию... не будет дано естественного исхода, то проявлениями своими оно может вредно повлиять на успешное приведение и дальнейшее развитие начал гражданственности в остальной части населения предкавказского края». В то же время закавказские земли представляют собой «свободную и удобную» территорию, открытую для переселения «недовольных» казаков, которые могут стать надежным «прикрытием границ с Турцией и Персией и упрочить нравственное влияние наше за Кавказом». Лорис-Меликов отдельно останавливается на «мусульманском» факторе, то есть, в его понимании, на присутствии «миллионного фанатического и еще вооруженного мусульманского населения Закавказских провинций, непосредственно примыкающего к почти полумиллионному мусульманскому же населению Дагестана», которые, в свою очередь, на русское владычество до сих пор смотрят как на временное явление. Поэтому начало военных действий с Османской империей, в описании Лорис-Меликова, постоянно сопровождается «грабежами и разбоями в пограничных мусульманских провинциях», а также «вторжением значительных хищнических партий... воинственных племен курдов и аджарцев, которые нападают на пограничные русские и армянские деревни и распространяют панику в мирном населении...» [7]. Таким образом, создание нового Закавказского казачьего войска, по мнению Лорис-Меликова, решит несколько проблем. Во-первых, позволит провести необходимые реформы среди «внутренних» казачьих войск, во-вторых, даст толчок «для естественного развития всех качеств казачества», и в-третьих, обеспечит безопасность для населения русско-турецкой границы. Завершая записку, Лорис-Меликов делает акцент на последней проблеме, по сути предсказывая ситуацию начала XX в., приведшую к трагедии армянского народа в 


\section{ВЛАСТЬ И ОБЩЕСТВО}

1915 году. «Я позволяю себе обратить внимание Вашего Высочества, - писал в заключении Лорис-Меликов, почти взывая к Александру II, - на то особое значение, какое получит Закавказское казачье войско в весьма, может быть, недалеком будущем, когда племя Османлы окончит свое политическое существование в Европе и станет искать опоры и силы в воинственных и полудиких племенах Малой Азии, чтобы, развив здесь новый центр мусульманского владычества, возобновить борьбу с Христианским миром, уже конечно при иных условиях, чем в Европе. Движимое мщением по самому духу религиозного учения своего, оно всею тяжестью фанатизма обрушится на значительные по численности, но неспособные к самостоятельному отпору христианские поселения Анатолии ${ }^{1}$, между которыми уже и теперь проявляется сознание конечной в таком случае гибели, если Правительство наше не откроет им приюта и спасения в Закавказском крае» [7, с. 152]. Этими словами Лорис-Меликов, армянин по происхождению, обнажил личные этноконфессиональные предпочтения, демонстрируя заинтересованность в казачестве как в средстве достижения важных для себя и своего народа целей. Александр II после прочтения записки собственноручно оставил на ней надпись и дату: «Мысль эту Я предварительно одобряю, но необходимо представить соображения, с исчислением нужных для того сумм. 15 января 1870 г.». Уже на следующий день военный министр Д.А. Милютин обратился в ГУИВ с поручением о необходимости подготовки письма на имя Наместника Кавказа и командующего Кавказской армией Великого князя Михаила Николаевича с изложением содержания записки и императорской резолюции. Министр также призвал включить в послание и «некоторые другие соображения», в том числе имея в виду «водворение в Закавказье русских сектантов». 28 января 1870 г. ГУИВ отправило соответствующее письмо Великому князю и запросило «подробных предложений... причем, конечно, - говорилось в послании, будет принят за основание тщательный осмотр и выбор тех местностей, которые могут иметься в виду для водворения казачьего населения, так как необходимо избегнуть местностей как весьма гористых, так и низменных, отличающихся вредным климатом» [19, л. 2, 20-20 об.].
Однако были ли проведены подобные работы, - неизвестно. Закавказское казачье войско образовано не было.

Таким образом, современный историк О. Кузнецов явно ошибался в своем утверждении: «К счастью, Александр II понял этот подтекст ${ }^{2}$ (то есть защита интересов армянского народа. $-A$. B.) докладной записки и оставил ее без высочайшего внимания» [12, c. 27]. Более того, очевидно, что допущенное Кузнецовым явно эмоциональное высказывание определено местом его публикации - в азербайджанском журнале «IRS Наследие» и относится скорее к проявлению исторической политики. Однако вряд ли упомянутый подтекст был доминирующим в принятии предполагаемого решения по «заморозке» предложений Лорис-Меликова. Как и в случае с несостоявшимся переселением казаков на западно-китайскую границу, отказ от создания отдельного казачьего войска в Закавказье, на наш взгляд, был обусловлен в первую очередь нежеланием властей вновь получить казачий протест. В том, что он произошел бы, если записке Лорис-Меликова был бы дан ход, у нас нет никаких сомнений.

Выводы. Составление в 1860-х гг. различных чиновничьих записок и проектов, в которых в качестве активных агентов фигурировали казачьи войска, это не уникальное явление в правительственной политике. Подобные документы разрабатывались и ранее как в центре, так и на местах. Окончание Кавказской войны и экспансия Российской империи в Средней Азии послужили мощным толчком для активного пересмотра в среде высшей бюрократии места и значения казачества как эффективной военной силы и колонизационного ресурса. Именно эти факторы (но не единственные) сделали 1860-е гг. периодом наиболее интенсивного обсуждения казачьего вопроса. В итоге часть войсковых казачьих структур подверглась реорганизации, появилось новое Семиреченское войско, а также были подготовлены проекты и записки по созданию еще новых войск и планов по переселению казаков на приграничные территории. Столкнувшись с казачьим сопротивлением при осуществлении колонизации Кавказа, власть, допуская в дальнейшем дебаты на заседаниях различных комиссий и выражения мнения высокопоставленных чиновников по по- 
воду способов использования казачества, на практике крайне осторожно подходила к реализации подобных идей, предпочитая «замораживать» их на проектной стадии. Как нам представляется, ответственным за формирование такой стратегии было ГУИВ, которое имело максимально полную информацию о состоянии дел в казачьих войсках, а также преследовало свои узковедомственные интересы. В разработке проектов по образованию новых войск и колонизационных планов принимало участиене только Военное министерство, но и другие ведомства, а также представители генерал-губернаторского корпуса. Этот факт можно расценить как сигнал, свидетельствующий о нарастающей утрате монополии Военного министерства по формированию казачьей политики в империи. Стоит также обратить более пристальное внимание на финансовые издержки при переселении казаков или образовании новых казачьих войск (о чем недвусмысленно писал сам Александр (I). Возможно, именно необходимость нести дополнительные затраты со стороны государственной казны останавливала имперские власти в шаге от положительного решения казачьего вопроса.

\section{ПРИМЕЧАНИЯ}

${ }^{1}$ Имеется в виду христианское население Османской империи (в основном греки и армяне), проживающие в Анатолии на территории шести восточных вилайетов, то есть османских административных единиц - провинций.

${ }^{2}$ Дословно об этом «подтексте» О. Кузнецов написал так: «...проект М.Т. Лорис-Меликова означал буквально следующее: переселяемые в Закавказье кубанские и терские казаки должны согнать с мест своего обитания полукочевые кавказские мусульманские народы, оттеснив их в Турцию и Персию. На освободившиеся земли из Османской империи начнут усиленно переселяться армяне, после чего в Закавказье они станут доминирующей этнической группой, и через несколько десятилетий закавказские православные казаки стануг охранять их экономические и религиозные интересы» [12, с. 27].

\section{СПИСОК ЛИТЕРАТУРЫ}

1. Абдиров, М. Ж. История казачества Казахстана / М. Ж. Абдиров. - Алматы : Изд-во «Казахстан», 1994. - $161 \mathrm{c}$.
2. Абдиров, М. Ж. Семиреченское казачье войско: из истории военно-казачьей колонизации Жетысу 1867-1917 гг. / М. Ж. Абдиров, 3. С. Актамбердиева. - Алматы : Изд-во Казах. нац. ун-та им. аль-Фараби, 2011. - 362 с.

3. Актамбердиева, 3. С. История Семиреченского казачьего войска (1867-1920 гг.) : автореф. дис. ... канд. ист. наук / Актамбердиева Зауре Салкеевна. - Алматы, 2007. - 24 с.

4. Анисимова, И. В. Роль Сибирского и Семиреченского казачьих войск в решении геополитических задач России в Центральной Азии / И. В. Анисимова // Востоковедные исследования на Алтае. - Барнаул, 2016. - Вып. 10. - С. 72-75.

5. Безвиконная, Е. В. Административная политика самодержавия в Степном крае (20-60-е гг. XIX в.) : дис. ... канд. ист. наук / Безвиконная Елена Владимировна. - Омск, 2002. - 332 с.

6. Васильев, Д. В. Бремя империи. Административная политика России в Центральной Азии. Вторая половина ХІХ в. / Д. В. Васильев. - М. : Полит. энцикл., 2018. -638 с.

7. Волвенко, А. А. «...роль и задача казачества на Северном Кавказе уже окончены...». Записка М.Т. Лорис-Меликова об образовании Закавказского казачьего войска / А. А. Волвенко // Восток: история, политика, культура. Научные труды Института бизнеса и политики. Вып. 4. - М. : Изд-во Ин-та бизнеса и политики, 2007. - С. 140-152.

8. Волвенко, А. А. Казачество и конскрипция в 1860-1870-е гг. / А. А. Волвенко // Российская история. -2018 . - № 5. - С. 36-45.

9. Всеподданнейший отчет о действиях Военного министерства за 1859 год. - СПб., $1862 .-443$ с.

10. Гаденко, А. П. Азовское казачье войско (1830-1865 гг.) / А. П. Гаденко. - Кашира : Тип. В.А. Третьякова, $1912 .-54$ с.

11. Короленко, П. П. Переселение казаков за Кубань в 1861 г. / П. П. Короленко // Кубанский сборник. T. XVI. - Екатеринодар, 1911. - С. 311-316.

12. Кузнецов, О. Закавказское казачье войско: три несостоявшихся проекта / О. Кузнецов // IRS Haследие: международный азербайджанский журнал. 2013. - № 2 (62). - С. 22-27.

13. Леденев, Н. В. История Семиреченского казачьего войска / Н. В. Леденев. - Верный : Тип. Семиреч. обл. правления, 1909. - 834 с.

14. Лещев, Е. Н. Охрана государственной границы Российской Империи Семиреченским казачьим войском (1867-1917 гг.) : дис. ... канд. ист. наук / Лещев Евгений Николаевич. - М., 2004. - 189 с.

15. Мацузато, К. Генерал-губернаторства Азиатской России: геополитика и территориальное управление / К. Мацузато // Личность, общество и власть в истории России : сб. науч. ст., посвящ. 70-летию д-ра ист. наук, проф. В. И. Шишки- 
на. - Новосибирск : Изд-во Сибир. отд-ния РАН, 2018. - C. 74-103.

16. Митропольская, Т. Б. Из истории Семиреченского казачества / Т. Б. Митропольская. - Алматы : ЭділетПресс, 1997. - 90 с.

17. О преобразовании управления сибирскими киргизами и переводе ГУЗС в г. Томск (1864 г.) // Исторический архив Омской области. - Ф. 3. Оп. 4. - Д. 5650. - 410 л.

18. О Семиреченском казачьем войске // Российский государственный военно-исторический архив (далее-РГВИА). -Ф. 330.-Оп. 11.-Д. 25. - 187 л.

19. Об образовании Закавказского казачьего войска // РГВИА. - Ф. 330. - Оп. 1. - Д. 131. - 20 л.

20. Проект положения об Уральском казачьем войске // РГВИА. - Ф. 330. - Оп. 1. - Д. 84. - 306 л.

21. Ремнев, А. В. Колонизация Азиатской России: имперские и национальные сценарии второй половины XIX - начала XX века / А. В. Ремнев, Н. Г. Суворова. - Омск : Наука, 2013. - 246 с.

22. Ремнев, А. В. На фронтирах империи. Казачество в колонизационных процессах конца XIX - начала XX века / А. В. Ремнев, Н. Г. Суворова // Tartaria Magna. - 2011. - № 1. - С. 16-36.

23. Сапунов, Д. А. Участие казачества Урала и Сибири в присоединении Средней Азии к России (4090-е гг. XIX века) : дис. ... канд. ист. наук / Сапунов Дмитрий Александрович. - Челябинск, 2001. - 255 с.

24. Сатанова, Л. М. Правовой статус Семиреченского казачьего войска (середина XIX - начало XX в.) : автореф. дис. ... канд. юрид. наук / Сатанова Л. М. - Алматы, 2006. - 34 с.

25. Столетие Военного министерства 1802-1902. Главное управление казачьих войск. Исторический очерк.-СПб. : Синод. тип., 1902.-Т. 11.-Ч. 1.-900 с.

26. Ярков, А. П. Казаки в Кыргызстане / А. П. Ярков. -Бишкек : Изд-воКРСУ, 2002. - 77 с.

\section{REFERENCES}

1. Abdirov M.Zh. Istoriya kazachestva Kazahstana [History of the Cossacks of Kazakhstan]. Almaty, Kazahstan Publ., 1994. 161 p.

2. Abdirov M.Zh., Aktamberdieva Z.S. Semirechenskoe kazach'e vojsko: iz istorii voennokazach'ej kolonizacii Zhetysu 1867-1917 gg. [Semirechenskoye Cossack Army: From History of the Military-Cossack Colonization Zhetys of 1867-1917]. Almaty, Kazahskij nacional' nyj universitet im. al'Farabi, 2011.362 p.

3. Aktamberdieva Z.S. Istoriya Semirechenskogo kazach'ego vojska (1867-1920 gg.): avtoref. dis. ... kand. ist. nauk [History of Semirechensky Cossack Army (1867-1920): The abstract of the thesis for a degree of the candidate of historical sciences]. Almaty, 2007.24 p.
4. Anisimova I.V. Rol' Sibirskogoi Semirechenskogo kazach'ih vojsk v reshenii geopoliticheskih zadach Rossii v Central'noj Azii [A Role of the Siberian and Semirechensky Cossack Troops in the Solution of Geopolitical Problems of Russia in Central Asia]. Vostokovednye issledovaniya na Altae. Barnaul, 2016, no. 10, pp. 72-75.

5. Bezvikonnaya E.V. Administrativnaya politika samoderzhaviya v Stepnom krae (20-60-e gg. XIX v.): dis. ... kand. ist. nauk [Administrative Policy of Autocracy in Steppes $\left(20-60^{\text {th }}\right.$ of the $19^{\text {th }}$ Century). Cand. hist. sci. diss.]. Omsk, 2002.332 p.

6. Vasil'ev D.V. Bremya imperii. Administrativnaya politika Rossii v Central'noj Azii. Vtoraya polovina $X I X v$. [Empire Burden. Administrative Policy of Russia in Central Asia. The Second Half of the $19^{\text {th }}$ Century]. Moscow, Politicheskaya Enciklopediya Publ., 2018. $638 \mathrm{p}$.

7. Volvenko A.A. «...rol' i zadacha kazachestva na Severnom Kavkaze uzhe okoncheny...». Zapiska M.T. Loris-Melikova ob obrazovanii Zakavkazskogo kazach'ego vojska [“...the role and a task of the Cossacks in the North Caucasus are already ended...”. M.T. LorisMelikov's Note About Education of the Transcaucasian Cossack Army]. Vostok: istoriya, politika, kul'tura. Nauchnye trudy Instituta biznesa i politiki. Moscow, Izd-vo In-ta biznesa i politiki, 2007, no. 4, pp. 140-152.

8. Volvenko A.A. Kazachestvo i konskripciya v 1860-1870-e gg [The Cossacks and a Konskription in the $1860-1870^{\text {th }}$. Rossijskaya istoriya, 2018, no. 5, pp. $36-45$.

9. Vsepoddannejshij otchet o dejstviyah Voennogo ministerstva za 1859 god [The Vsepoddanneyshy Report on Actions of the Ministry of Defence for 1859]. Saint Petersburg, 1862. 443 p.

10. Gadenko A.P. Azovskoe kazach'e vojsko (1830-1865 gg.) [Azov Cossack Army (1830-1865)]. Kashira, Tipografiya V.A. Tret'yakova, 1912. 54 p.

11. Korolenko P.P. Pereselenie kazakov za Kuban' v $1861 \mathrm{~g}$ [Resettlement of Cossacks for Kuban in 1861]. Kubanskij sbornik. Ekaterinodar, 1911, no. XVI, pp. 311-316.

12. Kuznecov O. Zakavkazskoe kazach'e vojsko: tri nesostoyavshihsya proekta [Transcaucasian Cossack Army: Three Cancelled Projects]. IRS Nasledie: mezhdunarodnyj azerbajdzhanski jzhurnal, 2013, no. 2 (62), pp. 22-27.

13. Ledenev N.V. Istoriya Semirechenskogo kazach'ego vojska [History of Semirechensky Cossack army]. Vernyj, Tip. Semirech. obl. pravleniya, 1909. 834 p.

14. Leshchev E.N. Ohrana gosudarstvennoj granicy Rossijskoj Imperii Semirechenskim kazach'im vojskom (1867-1917 gg.): dis. ... kand. ist. nauk [Protection of Frontier of the Russian Empire by Semirechensky Cossack Army (1867-1917). Cand. hist. sci. diss.]. Moscow, 2004. 189 p. 
15. Macuzato K. General-gubernatorstva Aziatskoj Rossii: geopolitika iterritorial'noe upravlenie [Governorate-Generals of Asian Russia: Geopolitics and Territorial Department]. Lichnost', obshchestvo i vlast' $v$ istorii Rossii: sb. nauch. st., posvyashch. 70-letiyu d-ra ist. nauk, prof. V.I. Shishkina. Novosibirsk, Izd-vo Sibirskogo otdeleniya RAN, 2018, pp. 74-103.

16. Mitropol'skaya T.B. Iz istorii Semirechenskogo kazachestva [From History of the Semirechensky Cossacks]. Almaty, EdiletPress, 1997.90 p.

17. O preobrazovanii upravleniya sibirskimi kirgizami i perevode GUZS v g. Tomsk (1864 g.) [About Transformation of Management of the Siberian Kyrgyz and Transfer of GUZS to Tomsk (1864)]. Istoricheskij arhiv Omskoj oblasti, f. 3, op. 4, d. 5650. 4101.

18. O Semirechenskom kazach'em vojske [About Semirechensky Cossack Army]. Rossijskij gosudarstvennyj voenno-istoricheskij arhiv (RGVIA), f. 330, op. 11, d. 25.1871.

19. Ob obrazovanii Zakavkazskogo kazach'ego vojska [On the Formation of the Transcaucasian Cossack Troops]. RGVIA, f. 330, op. 1, d. 131. 201.

20. Proekt polozheniya ob Ural'skom kazach'em vojske [Draft of the Provision on the Ural Cossack Army]. RGVIA, f. 330, op. 1, d. 84. 3061.

21. Remnev A.V., Suvorova N.G. Kolonizaciya Aziatskoj Rossii: imperskie $i$ nacional'nye scenarii vtoroj poloviny XIX-nachala XX veka [Colonization of Asian Russia: Imperial and National Scenarios of the Second Half of XIX - the Beginning of the $20^{\text {th }}$ Century]. Omsk, Nauka Publ., 2013. 246 p.

22. Remnev A.V., Suvorova N.G. Na frontirah imperii. Kazachestvo v kolonizacionnyh processah konca XIX - nachala XX veka [On the Frontirakh of the Empire. The Cossacks in the Kolonizatsionnykh Processes of the End of XIX - the Beginnings of the $20^{\text {th }}$ Century]. Tartaria Magna, 2011, no. 1, pp. 16-36.

23. Sapunov D.A. Uchastie kazachestva Urala $i$ Sibiri v prisoedinenii Srednej Azii k Rossii (40-90e gg. XIX veka): dis. ... kand. ist. nauk [Participation of the Cossacks of the Urals and Siberia in Accession of Central Asia to Russia (40-90 $0^{\text {th }}$ of the $19^{\text {th }}$ Century). Cand. hist. sci. diss.]. Chelyabinsk, 2001.255 p.

24. Satanova L.M. Pravovoj status Semirechenskogo kazach'ego vojska (seredina XIXnachalo XXv.): avtoref. dis. ... kand. yurid. nauk [Legal Status of Semirechensky Cossack Army (Middle the XIX Beginning of the $20^{\text {th }}$ Century of Century). Cand. jurid. sci. abs. diss.]. Almaty, 2006. 34 p.

25. Stoletie Voennogo ministerstva 1802-1902. Glavnoe upravlenie kazach'ih vojsk. Istoricheskij ocherk [Century of the Ministry of Defence of 18021902. Head Department of the Cossack Troops. Historical Sketch.]. Saint Petersburg, Sinod. tip., 1902. vol. 11, pt. 1.900 p.

26. Yarkov A.P. Kazaki v Kyrgyzstane [Cossacks in Kyrgyzstan]. Bishkek, KRSU, 2002. 77 p.

\section{Information About the Author}

Alexey A. Volvenko, Candidate of Sciences (History), Associate Professor, Deputy Director for Scientific Affairs, Taganrog Institute named after A.P. Chekhov (branch) RSUE (RINH), Initsiativnaya St, 48, 347936 Taganrog, Russian Federation, avolvenko@mail.ru, https://orcid.org/0000-0002-6932-5976

\section{Информация об авторе}

Алексей Александрович Волвенко, кандидат исторических наук, доцент, заместитель директора по научной работе, Таганрогский институт им. А.П. Чехова (филиал) Ростовского государственного экономического университета (РИНХ), ул. Инициативная, 48, 347936 г. Таганрог, Российская Федерации, avolvenko@mail.ru, https://orcid.org/0000-0002-6932-5976 